
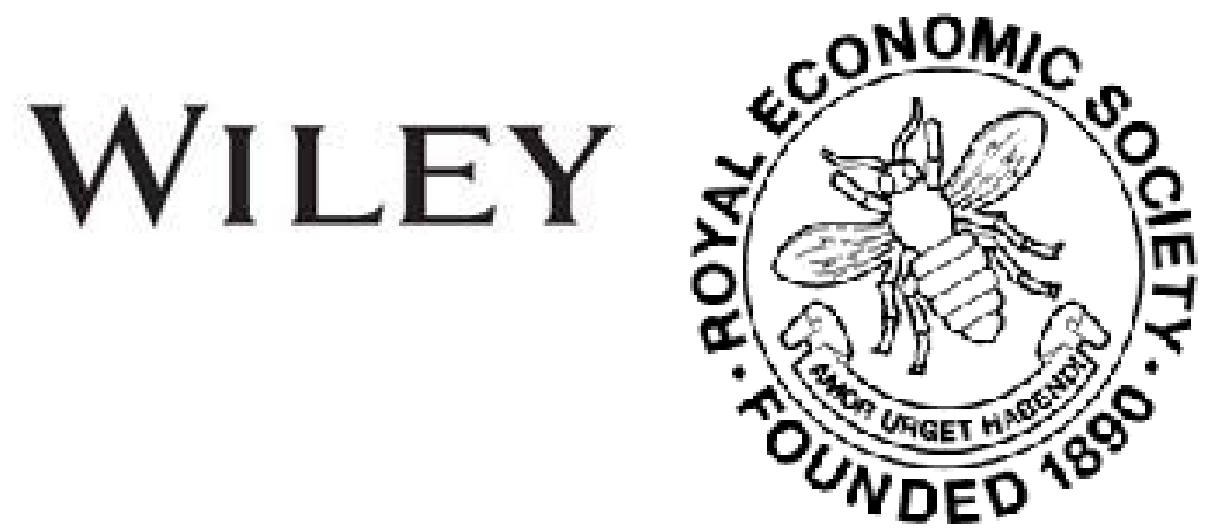

The Selling and Financing of the American Cotton Crop Author(s): R. C. Wyse

Source: The Economic Journal, Vol. 30, No. 120 (Dec., 1920), pp. 473-483

Published by: Wiley on behalf of the Royal Economic Society

Stable URL: http://www.jstor.org/stable/2222871

Accessed: 19-06-2016 21:14 UTC

Your use of the JSTOR archive indicates your acceptance of the Terms \& Conditions of Use, available at

http://about.jstor.org/terms

JSTOR is a not-for-profit service that helps scholars, researchers, and students discover, use, and build upon a wide range of content in a trusted digital archive. We use information technology and tools to increase productivity and facilitate new forms of scholarship. For more information about JSTOR, please contact support@jstor.org.

Wiley, Royal Economic Society are collaborating with JSTOR to digitize, preserve and extend access to The Economic Journal 


\section{THE SELLING AND FINANCING OF THE AMERICAN COTTON CROP}

IT may not be out of place by way of preface to make some observations on the world's cotton crop. Probably about 25 million bales of $500 \mathrm{lb}$. are produced annually, the United States' contribution being between 50 and 60 per cent. normally of this total, India's share being about 20 per cent., China's about 15 per cent., and Egypt's about 5 per cent.

The annual value of the United States' crop, for the last few years, of raw cotton grown in that country is probably somewhere about $£ 350,000,000$ to $£ 375,000,000$ in gold dollar value (1916, $\$ 1,866,240,000 ; 1919, \$ 1,710,715,068)$, about half the crop $(6,000,000$ bales, $1918-19 ; 6,100,000,1919-20)$, being consumed in the United States, Great Britain and the Continent, etc., taking the other half (Great Britain, 1918-19, 2,650,000; 1919-20, $3,000,000$; Continent, etc., 1918-19, 2,800,000; 1919-20, $3,400,000)$.

The last big crop in the United States occurred in 1914-15about $16 \frac{1}{2}$ million bales. Since then the annual yield has been round about 12 million bales, although the final yields are mostly in excess of the estimates. The proverbial optimism of the American appears to evaporate altogether when he makes his annual summer estimates of what the American cotton crop will produce.

Our imports and exports of cotton (from and to all countries) for :-

\begin{tabular}{|c|c|c|c|c|c|c|}
\hline \multirow{2}{*}{$\begin{array}{cr}\text { Value of } & \text { Imports } \\
, \quad \text { Exports }\end{array}$} & \multicolumn{2}{|c|}{$\begin{array}{c}1918 . \\
£ 150 \text { millions }\end{array}$} & \multicolumn{2}{|c|}{$\begin{array}{c}1919 . \\
£ 190 \text { millions }\end{array}$} & \multicolumn{2}{|c|}{$\begin{array}{c}1920 . \\
£ 250 \text { millions }\end{array}$} \\
\hline & $£ 180$ & , & $£ 251$ & , & $\mathfrak{f} 430$ & , \\
\hline & $£ 30$ & ," & $\mathfrak{£} 61$ & ," & $£ 180$ & , \\
\hline
\end{tabular}

(Note.-The figures for 1920 are estimated.)

Our imports of cotton were :-

1918.

$£ 95$ millions

1918.

$\mathfrak{f 5 0}$ millions

1918.

f5 millions
From U.S.

1919.

$£ 125$ millions

From British Sources.

1919.

$£ 57$ millions

Foreign Sources other than U.S.

1919.

£8 millions

* Eight months only.
$1920 .^{*}$

$\mathfrak{1 2 8}$ millions

1920.*

$\mathfrak{f 5 8}$ millions

$1920 . *$

$\mathfrak{1} 14$ millions 
It will be seen that two-thirds of the total cost of our raw cotton imports goes to the United States; it is also estimated that about 75 per cent. of the output of cotton mills in Great Britain is exported, leaving the balance for domestic consumption. More than 600,000 people are actually engaged in this country in the spinning and weaving of cloth, the number of our population dependent on the cotton trade being believed to be over three millions. This year about one-third in money value of our total exports will come from the cotton industry.

Our manufactured and partly manufactured exports in 1920 for eight months, compared with 1919 for a similar period, have about doubled in money value-£740 millions versus $£ 385$ millions -and it may be fairly assumed that as we pay more promptly for our imports than we obtain payment for our exports, the effect of this on credit expansion must be very considerable, and to some degree expląins the restrictions that the banks are now compelled to impose on further demands for fresh credit facilities from their customers.

Sir Charles Macara, in a letter on August 24th to the British Empire Review, in emphasising the bearing on production of the cotton operatives' shorter hours and the large amount of cotton machinery that is idle in the world from various causes, stated that raw cotton material takes six, nine, twelve months, and even longer, to pass through the numerous processes before the current stock of manufactured goods is increased. In 1919 the production of cotton cloth was only $3 \frac{1}{2}$ million yards as against over 7 million yards in 1913, whereas the actual money value of the cloth manufactured in 1919 was approximately double that of 1913. Slow production and high prices tie up banking credits, and if, added to these factors, manufactured goods themselves do not go into quick consumption, the burden on banking credits is obvious and may become unbearable sooner or later.

Russia is probably the only important cotton-growing area $(1,300,000$ bales in 1914-15) which is not growing this crop now to the same extent as in pre-war times, but that fact will only increase her present domestic misery, as she was formerly a large importer also. With a carry-over in America this season of about 7 million $(6,800,000)$ bales old crop, and with the largest new American crop in sight (13 million bales or more) since 1914, and no evidence of short cotton crops in other countries, it is hard to believe that there is not enough of raw cotton in existence to more than satisfy the world's present demands. 


\section{Financing and Selling in the United States.}

It may not be inappropriate before sketching out how cotton is financed and sold in the United States to quote here what occurred in September last when a deputation from the American Cotton Association met the Governor of the Federal Reserve Board to secure a definite understanding as to the Board's attitude in regard to the financing of the cotton crop-a request being also made for credit assistance from the Board for $\$ 500,000,000$ against five million bales at 20 cents a pound, in order to provide for the orderly marketing of the cotton crop during the coming winter. The Governor replied: "I don't think you will work out the situation by demanding any more extension of loans than is now going on. I think the thing you gentlemen should do is to go back home, tell your people to quit talking calamity, and make the best of a bad situation. You want $\$ 500,000,000$ more on cotton loans; if the Board would undertake to find credits for all agricultural products, it would take about three thousand million dollars additional in loans. We have shown our good faith in taking money from the East and putting it in the South, but the time has got to come when they will want their money back. You have got a problem here in your low-grade cotton" (he was apparently referring to the carryover of 6,800,000 bales) - "I think that is your main problem. Looking at the thing broadly, it seems to me that you should get it into your heads that it is not the Board's business to deal in prices. If we made the loans you ask for, besides being a serious drain upon the Federal system, it would have an effect on wages."

American middling cotton on July 31 st last was 43.75 cents, on September 10 th it was 32.25 cents per lb., by October 11 th the quotation had fallen to 23 cents, so it is obvious that the Governor's advice had some material effect on the price of raw cotton.

In August a Convention of the American Cotton Association at Montgomery (Ala.) approved a recommendation that the minimum price for cotton up to November 1st should be 40 cents per $\mathrm{lb}$., increasing 1 cent monthly thereafter till the entire crop had been marketed. Reports are appearing in the Press from time to time that the cost of cotton production is between 35 and 43 cents per $\mathrm{lb}$. This is surely propaganda. Recently an American international banker-from New Orleans, whose banking career had been largely spent in that cotton centre-gave it as his opinion that, after making full allowance for the high 
cost of labour in the South to-day, and for everything else, the actual cost of production might truly be described as around 20 cents, or about half the amount claimed.

The cotton surplus already mentioned as carried over from last season, plus thirteen million bales of new crop, with a poor demand for the raw material, either in the United States or elsewhere, makes a holding up campaign beyond the power of even big America.

One can form some idea from these comments of the magnitude of the banking credit necessary to finance the raw material where it is grown, and the further immense credits that have to be found in America and abroad during the period covering its manufacture into cloth.

Credit is utilised from the time the seed is planted. The American cotton farmer generally makes a good living nowadays -but not much more-from his occupation. A fair proportion own their farms, the majority probably rent them from the great plantation owners and syndicates. Only a small number can carry through on their own resources from seed-time till the crop is picked. The country storekeeper, in return for a lien on the crop, allows the farmer credit at his store, and this is redeemed when the cotton is taken over by the storekeeper at harvest-time. If there is a surplus to the farmer's credit, after interest, etc., is allowed for-on the accommodation given-he then gets it. The country storekeeper is usually in the employment of a local cotton factor, or he may be the local agent of the proprietors of the larger plantations who rent these out in small sections. The proprietors of the large plantations are mostly substantial men with means, whose credit is good, and any further financial assistance needed during the growing season they can ordinarily obtain by borrowing on their promissory notes from bill brokers or bankers.

The cotton factors are really the commercial bankers of the industry, and they are usually affiliated with some large bank, on whom they can rely for additional credits during the heavy seasonal pressure.

When the cotton reaches the gin or compress, gin receipts or compress receipts come into existence, and these are used as collateral by the buyers, who borrow from the local banks in order to pay cash to the growers. The loans made by local banks are repaid when the exchange of these receipts into inland bills of lading is effected. The ladings are then attached to drafts drawn on the buyers' agent or the buyers' head office in America. 
If the cotton is sold abroad, the local banker exchanges the gin or compress receipts for through or port bills of lading, and attaches these to a foreign bill of exchange, which, if he deals in foreign exchanges, he may buy himself and transmit to Europe, or send the exchange to New York, or other American city with a foreign exchange market, for sale and credit at current rates.

Usually these Southern banks are large borrowers from the New York banks during the cotton season, and the New York banks transacting foreign exchange business are naturally anxious to make such loans to the Southern banks, since for these they obtain good interest rates, and, in addition, from the same borrowers, large supplies of foreign exchanges, the proceeds of which are often used to repay these loans. This may be described as intensive banking for the lenders, who secure two profits where only one is ordinarily obtainable.

The concentration of sterling cotton bills through one or two American banks in London during the last ten or fifteen years has been largely built up by the intimate associations that now exist between the big New York deposit banking institutions possessing foreign offices and the Southern banks.

The financing of cotton in America-and perhaps in the future in Europe as well of the exported cotton-lies in the hands of these powerful American banks, should America be able to provide a cheaper supply of credit for financing these cotton exports in the importing countries than these countries can themselves.

It was on the free conversion of credits into gold and low and stable discount rates that we built up the London acceptance business-without either, can we confidently expect to retain the financing here of our imports of American cotton, which financing naturally lies within America's grasp if her domestic money conditions are sufficiently favourable? America's financing of our cotton imports under these conditions would be profitable to Lancashire, although depriving Lombard Street of a large part of its supply of the finest bank paper and the clearing banks of their relative acceptance commissions.

\section{EXCHANGE.}

Liverpool buys cotton in sterling at so much pence per lb. c.i.f. This means that the dollar exchange value of the pound sterling is also included in the "all-in" sterling price asked for the cotton by the American seller. In other words, the American seller takes the risk of getting his anticipated dollar price for the cotton sterling price he makes, and with this aspect of his sale 
the Liverpool buyer has no direct concern. When a Liverpool buyer buys either for spot or future delivery he immediately cables his American seller how the reimbursement is to be effected. This reimbursement is almost always done by sixty days' sight drafts-occasionally ninety days-on the best English banks, accompanied by bills of lading and certificates of insurance for the cotton, which sterling exchange the American seller promptly places with an American exchange bank for spot or forward delivery, thus eliminating, so far as the seller is concerned, the factor of exchange risk. In computing the price of the cotton offered abroad in a foreign currency, the American seller has, of course, to make sure that he has an American exchange bank ready to pay to him the dollar price he expects for his exchange, if his prospective foreign buyer of the cotton accepts, otherwise the transaction might result in a loss through depreciation meantime of the foreign currency in which he offered to sell.

The New York exchange market is very highly organised and efficient nowadays, and generally close prices are given to real traders for spot and future deliveries of sterling exchange, which enable these exporters to consummate their international sales on keen terms with little risk to them of exchange loss.

This is particularly true as regards the cotton trade, for as these sterling exports from America are financed by clearing bank drafts, the relative credit risk to the American exchange banks on such prime acceptors is practically a negligible one. The actual risk the American exchange banks really run, until acceptance is secured, is a short and moral one on the American cotton drawers, the drafts being accompanied until accepted by the drawee banks by shipping documents for the cotton drawn against.

Generally, the big American exchange banks keep a square book on future deliveries, and the remuneration they require for such high-class business is a trifling premium relative to the small risk involved.

Were the American cotton sellers unwilling to sell in sterling - for since the war they have refused to sell in French and Belgian francs and in other European currencies, more uncertain and more depreciated than sterling - and exacted payment in dollars, it would then devolve upon Liverpool importers to furnish dollar payments to meet their purchases.

The Liverpool cotton people have so long been accustomed to buy in sterling that they do not seem anxious at present to 
consider any change, and so far the American cotton exporters have not asked for a dollar price in place of a sterling one.

But if it should happen that the New York money market became so much cheaper than ours for financing American cotton imported here, then dollar credits would become more attractive to Liverpool than sterling credits, and eventually lead to the purchase of cotton in dollars by Liverpool, thus throwing the exchange covering of these purchases and of any dollar credits granted upon this side of the Atlantic.

\section{FUTURes.}

On the subject of futures the following questions have been asked :-

(1) Does the grower of cotton ordinarily cover himself by a sale of futures?

(2) Does the American factor or merchant do so?

(3) Does the ultimate cotton goods' buying merchant at home or abroad who buys such goods for delivery months after his ordering them cover himself by selling futures of raw cotton?

The broad answers to questions Nos. (1) and (3) are in the negative, to No. (2) in the affirmative. Ordinary cotton farmers are like other farmers, generally men with little or no capital, and who therefore are not in a position to find any additional money to pay differences that might be called for on sales of futures, even though such differences were represented by the increased value of their actual crop.

Supposing they had the means or the credit to enable them to operate in futures, they probably have not the skill and knowledge to protect themselves through this channel.

Besides, cotton farmers are nearly always bullish, and unlikely to sell forward at a discount on spot quotations-and especially before they know what their crops are actually going to be. Slumps in price usually take place when the size of the crop has become common knowledge; then the tendency of the producer when the crop is large is to expect better prices by holding off selling, unless there is someone in a position to sell him out, which probably is what most often happens.

The ultimate buying merchant of cotton piece goods relies mainly on his local market to pay him the price at which he bought the goods forward. He would, in most cases, be disinclined to hedge on raw cotton as this might entail his finding fresh capital to finance his purchased goods before these were under his control and could be used as collateral for borrowing 
the additional money required. If the ultimate buying merchant were in a silver-using country, he might use the silver futures market for hedging his purchases, but the same possibility of having to provide further money to keep the protection in force on the basic goods would perhaps make for second thoughts and inaction.

Of course, if one could be certain that prices were going down, a hedging sale would be simplicity itself.

The cotton futures market is designed primarily for those engaged in the cotton industry - the American factors and British and American cotton merchants and manufacturers. This class of trading serves to stabilise the whole industry and limits speculation by the trade itself.

The annual American crop is probably sold from twenty to forty times over on the cotton exchanges. New York cotton exchange has traded in one million bales in one day, and half that figure is not abnormal. The outside public, more especially in the United States, at times undoubtedly speculates heavily in cotton and accentuates the violence of the price movements.

The Liverpool cotton merchants do not to any material extent take up uncovered positions. Their bankers always presume that if their cotton clients buy or sell cotton, they invariably hedge themselves. If it were known they were speculating, their credit facilities at the banks would be curtailed, if not withdrawn altogether.

There is a prevalent idea that futures afford a more complete protection than they actually do. For example, it is believed by those outside the trade that when Manchester buys cotton from Liverpool and the Liverpool seller puts out a future pending his purchase in America of the precise grade of cotton sold that all is well and no danger of loss exists for the seller in the meantime. That, however, is not so. If the Manchester buyer has bought a grade of cotton, as usually happens, so many "points on " the future basis, these "points on" are not covered at all by the futures put out. To that extent the risk taken by the seller is his own till the actual cotton is bought as cover and the future is closed out. These "points on" are relatively high nowadays and may be 30 per cent. or more of the value of the cotton sold.

The future contract itself is a wide one, in the grades of cotton that are tenderable under it. No buyer on the cotton market, a spinner particularly, would care to buy actual cotton by futures, as he would seldom or never get the right sorts or 
adequate quantities of the sort he wanted under such a contract. Futures, therefore, only afford some basic protection against loss.

Here is a description of the process of hedging by a former President of the New York Cotton Exchange: "A hedge or future is the purchase or sale of contracts for 100 or more bales of cotton for future delivery made not for the purpose of receiving or delivering actual cotton, but as an insurance against fluctuations in the market that might unfavourably affect other ventures in which the buyer or seller is actually engaged."

\section{The Financing and Selling in England.}

Reverting to the account given above of the financing of raw cotton on the other side, the reader will remember that where the cotton is sold abroad it is represented by shipping documents attached to, say, a 60-days' or 90-days' sterling bill of exchange, drawn on an English bank, which the American cotton exporter had sold to an American exchange bank. This bank would get its money back by selling an equivalent amount of sterling to a buyer who required remittances of such a kind, and any surplus that arose over the purchase and sale after all expenses had been met would be the American exchange bank's profit.

The American exchange bank would, of course, transmit the cotton bill to its London correspondent or London office for acceptance by the drawee, and for discount when required. Sixty or ninety days after acceptance the bill would be paid by the acceptor-the English bank. Meantime the bank would retain the documents attached to the bill when presented for acceptance. The bank has, therefore, security for its acceptance, and if the cotton arrived before the acceptance is due, the cotton can be passed on to the next buyer and fresh security or cash be deposited with the bank, so that it remains secured against its outstanding unmatured acceptance.

If the cotton is not sold when the acceptance is paid, the bank may probably continue the amount paid as a cash advance against the deposited cotton. Or the bank's client may arrange for a London merchant banker to give him a credit on the same cotton for a further period or periods, depositing with this new acceptor the warehouse receipts for the cotton as security.

If the cotton has been sold to a spinner by the Liverpool merchant, he may draw long bills on the spinner, and hand these to the accepting Bank or, by arrangement with that bank, to a discount house for discount, and with the proceeds the bank's acceptance at maturity will be paid. 
When the spinner sells to the manufacturer, the latter often pays the spinner out of loans or bank overdrafts, which are liquidated when the Manchester merchant pays for the piece goods he has bought. To obtain these funds, the merchant either draws bills under credits opened for him by merchant bankers in London, or under credits placed at his disposal by his foreign buyers. Or, again, he may get advances from the Eastern, South American, or other Overseas banks against the deposit of his documentary drafts drawn on his foreign buyers. It is, of course, the affair of these foreign buyers to protect their purchases against fluctuations of exchange, as dealings are always in sterling. Doubtless the largest oversea firms do what is prudent in this connection, but there are some who, through ignorance or speculative tendency, take risks that frequently bring trouble to themselves and to others eventually.

The fall that has occurred in the silver exchanges during thie year is a case in point, causing anxiety, if not definite loss, in various quarters. Cancellation of orders, about which so much has been heard during the last six months, indicates that all the buying orders given from abroad were not based on sound business principles. Abnormally active trade in any market brings in a fresh class of trader of an abnormal brand, and the reactions that invariably develop are largely due to the manner in which this class of trader operates.

A certain literary man once remarked that "nothing succeeds like excess." Were he alive now he might have been tempted to add, as an exception to this rule, the E.P.D. The trouble about all excesses is that they have limits beyond which something very unpleasant happens. The world has had, and is still having, an excess of wars, high prices, currencies, banking credits, and also of advice from politicians. Since they handed out their Peace Treaty we have almost daily been told to "produce," "produce" and all would be well. Production is only useful if the corresponding consumption is at hand.

The pre-war nations had a working sort of relationship with each other in agriculture, in industry, and in commerce, and the prices of most things had a relative basis. Millions of people are now outside the effective world market. Those now inside that market are producing many things in excess of their internal needs. Textiles, tea, rubber, hides, and ships, for example, might be mentioned, and, as a consequence, the insiders are short of many things which those outside formerly produced for them and exchanged for the surpluses now appearing. 
What is the use of telling Lancashire, with its short time, and its yardage output only half of 1913 , to increase production when buyers are insufficient? You cannot now have millions of people outside the world market without disastrous results to everyone -in a world that was organised before the war on the basis of the inclusion of all producers and consumers. The peoples of Central and South-Eastern Europe and of the old Russia must be promptly got into the world's market again, otherwise the economic and political condition of those now inside the effective market may soon become not unlike the condition of those outside.

That is a vital problem which the Allies and America ought to have dealt with in Paris in 1919.

R. C. WYSE 